\title{
The Cohesion's Elements of Education Articles in Kompasiana
}

\author{
Fathurrohman Gala Sanca*), \\ SD Integral Al Husna \\ Erna Megawati, \\ Universitas Indraprasta PGRI \\ Azhari Ikhwati, \\ Universitas Indraprasta PGRI \\ *) Correspondences author: Jl. A. Damyati, Kota Tangerang, 15119, Indonesia; \\ e-mail: fathurrohmangalasanca@gmail.com
}

\begin{abstract}
The purpose of this study is to describe the kind of grammatical and lexical cohesion that used in education articles written by Syarifudin Yunus. The method that used in this study is qualitative descriptive method. Data source that used in this study are 24 education articles written by Syarifudin Yunus at Kompasiana.com web page in 2019 until 2020 year range. Technic that used in this study is basic technique of agih method or also called the BUL technique (For Direct Elements). The results of this study showed that there are four aspects of grammatical cohesions. The finding percentage of grammatical cohesion of this study are $54.4 \%$ conjunctions aspect, $35.4 \%$ references aspect, $6.1 \%$ substitutions aspect, and $4.1 \%$ ellipsis aspect. Besides, there are six lexical cohesion that found in this study. The percentage of lexical cohesions in this study are 63.5\% repetition aspects, $14 \%$ equivalency aspects, $8.8 \%$ collocation aspects, $7.2 \%$ synonym aspects, $3.8 \%$ hyponyim aspects, and $2.7 \%$ antonym aspects. This study can be implicated for Indonesian language learning at junior high school and senior high school.
\end{abstract}

Keywords: Grammatical cohesion; lexical cohesion; discourse.

Article History: Received: 08/12/2021; Revised: 16/12/2021; Accepted: 24/12/2021; Published: 30/12/2021

How to Cite (MLA $7^{\text {th }}$ ): Sanca, Fathurrohman Gala, Erna Megawati, and Azhari Ikhwati. “The Cohesion's Elements of Education Articles in Kompasiana." Hortatori Jurnal Pendidikan Bahasa dan Sastra Indonesia 5.2 (2021): 118-127. Print/Online. Copyrights Holder: Fathurrohman Gala Sanca, Erna Megawati, Azhari Ikhwati. First Publication: Hortatori Jurnal Pendidikan Bahasa dan Sastra Indonesia (2017).

This work is licensed under a Creative Commons Attribution-ShareAlike 4.0 International License.

\section{Pendahuluan}

Pembelajaran bahasa Indonesia di tingkat sekolah perlu mengarahkan peserta didiknya agar dapat menulis wacana yang baik dan benar. Dalam artikel publikasi Anita Sulistyaningsih memaparkan bahwa siswa kelas VII SMPN 3 Colomadu tidak memerhatikan kepaduan wacana yang ditulis. Padahal, kepaduan wacana merupakan syarat agar suatu wacana dapat menjadi wacana yang kohesif dan logis. Hal ini yang mendorong peneliti untuk melakukan penelitian analisis wacana kohesi gramatikal dan leksikal.

Van Dijk (dalam Arifin dkk., 2013:5) menyatakan bahwa analisis wacana yang dimaksudkan sebagai suatu analisis yang membongkar makna dan maksud-maksud tertentu. Menurut Chaer (dalam Dwinuryati, dkk. 2018:62) wacana merupakan satuan bahasa yang memiliki hierarki gramatikal tertinggi dalam bahasa. Wacana dibagi menjadi dua bentuk yaitu wacana lisan dan wacana tulis. Wacana lisan memiliki keterkaitan yang dinyatakan secara implisit dan kejelasan informasinya didukung oleh konteks. Sedangkan wacana tulis dinyatakan secara eksplisit yang merupakan rangkaian antarkalimat secara gramatikal. 
Wacana tulis menjadi bahan yang menarik untuk dikaji. Wacana tulis yang berasal dari berbagai media cetak seperti surat kabar, majalah, artikel, novel, cerpen, dan sebagainya dapat dikaji dari bentuk gramatikal, leksikal, maupun segi konteks. Hal inilah yang membuat peneliti tertarik untuk melakukan penelitian pada artikel di Kompasiana.

Kompasiana dipilih untuk pengambilan data dalam penelitian ini karena Kompasiana merupakan satu dari sepuluh media digital terbesar di Indonesia. Kompasiana juga memiliki 355.000 penulis dengan 26 juta pembaca setiap bulannya. Selain itu, Kompasiana selalu memuat tulisan baru dan mengikuti berita sedang hangat diperbincangkan. Berdasarkan data statistik Kompasiana per Desember 2017, tercatat hampir 300 artikel yang dipublikasikan setiap harinya.

Kompasiana memuat banyak artikel yang dapat digunakan peneliti untuk melakukan analisis wacana ini. Adapun artikel yang dipilih adalah artikel dengan tema pendidikan yang ditulis oleh Syarifudin Yunus pada tahun 2019 dan 2020. Syarifudin Yunus merupakan seorang pegiat literasi dan dosen di Universitas Indraprasta PGRI. Tercatat di Kompasiana, beliau sudah menulis sejak 14 Oktober 2012 dan menghasilkan 1.373 artikel dengan jumlah pembaca mencapai 1.138.805.

Menurut Djajasudarma (dalam Astuti, 2019:365) wacana yang padu dapat diciptakan dengan menggunakan penanda kohesi. Kohesi merupakan hubungan perkaitan antarproposisi yang dinyatakan secara eksplisit oleh unsur-unsur gramatikal dan semantik dalam kalimat-kalimat pembentuk wacana. Kohesi juga merupakan hubungan perkaitan antarproposisi, tetapi perkaitan tersebut tidak secara eksplisit atau nyata dapat dilihat pada kalimat-kalimat yang mengungkapkannya.

Menurut Halliday (dalam Mulyana, 2005:26) ada dua aspek dalam kohesi wacana yaitu kohesi gramatikal dan kohesi leksikal. Kohesi gramatikal antara lain adalah referensi, substitusi, elipsis, dan konjungsi, sedangkan yang termasuk dalam kohesi leksikal adalah sinonim, repetisi, kolokasi. Menurut Sumarlam (2008:23 dan 35) aspek gramatikal dalam wacana meliputi pengacuan, penyulihan pelesapan, dan perangkai, sedangkan pada aspek kohesi leksikal dalam wacana meliputi repetisi, sinonim, kolokasi, hiponimi, antonimi, dan ekuivalensi. Peneliti menggunakan teori Sumarlam dalam penelitian ini karena dianggap lebih lengkap dari teori Halliday.

Penelitian mengenai analisis kohesi wacana sudah pernah dilakukan oleh peneliti-peneliti sebelumnya. Penelitian Hasibuan (2016) dengan judul Analisis Penanda Kohesi Gramatikal Artikel Politik pada Media Online Kompasiana.com. Hasil penelitian tersebut mengungkapkan bahwa terdapat empat artikel yang memiliki kohesi gramatikal konjungsi lebih banyak dari tujuh artikel politik yang dipilih. Perbedaan penelitian tersebut dengan penelitian ini adalah penelitian di atas hanya mengkaji penanda kohesi gramatikal, sedangkan penelitian ini mengkaji penanda kohesi gramatikal dan leksikal.

Penelitian lain dilakukan oleh Muhammad Amin, dkk. (2016) dengan judul Kohesi dan Koherensi dalam Artikel Ilmiah Populer Radar Sulteng. Hasil penelitian tersebut menunjukkan bahwa bentuk yang paling banyak digunakan adalah kohesi gramatikal kategori konjungsi dengan persentase $30 \%$ dan kohesi leksikal kategori repetisi dengan persentase $6,7 \%$. Perbedaan penelitian tersebut dengan penelitian ini adalah penelitian di atas hanya mengkaji aspek kohesi dan koherensi, sedangkan penelitian ini hanya mengkaji aspek kohesi.

Penelitian kohesi wacana juga pernah dilakukan oleh Hardiaz (2020) dengan judul Kohesi Gramatikal dan Kohesi Leksikal dalam Novel Kubah Karya Ahmad Tohari dan Implikasinya terhadap Pembelajaran Bahasa Indonesia di SMA. Penelitian tersebut menemukan 103 data, kohesi gramatikal 62 data dan kohesi leksikal 41 data. Perbedaan penelitian tersebut dengan penelitian ini adalah penelitian di atas mengkaji novel sebagai bahan penelitian, sedangkan penelitian ini mengkaji artikel dari laman web Kompasiana.

Berdasarkan uraian di atas, dapat disimpulkan tujuan dari penelitian ini yaitu: 1). mendeskripsikan jenis kohesi gramatikal dan leksikal yang digunakan pada artikel tema pendidikan karya Syarifudin Yunus; 2). Mendeskripsikan hasil analisis kohesi gramatikal dan leksikal yang digunakan pada artikel pendidikan karya Syarifudin Yunus.

Penelitian ini diharapkan dapat diimplikasikan pada pembelajaran bahasa Indonesia di tingkat sekolah menengah pertama (SMP) ataupun sekolah menengah atas (SMA). Implikasi yang dapat diterapkan dalam pembelajaran bahasa Indonesia yang dapat meningkatkan pemikiran peserta didik yang lebih kritis terhadap suatu masalah yang berkembang di masyarakat. Adapun kompetensi berpikir kritis pada jenjang SMA terdapat pada kompetensi dasar 3.3., yaitu menganalisis teks cerita sejarah, berita, iklan, editorial/opini, dan novel baik melalui lisan maupun tulisan. Sedangkan kompetensi berpikir kritis pada 
jenjang SMP terdapat pada kompetensi dasar 3.6., yaitu menelaah isi dan struktur teks eksposisi berupa artikel ilmiah populer dari koran atau majalah yang diperdengarkan atau dibaca.

\section{Metode}

Pendekatan yang digunakan dalam penelitian ini adalah pendekatan kualitatif. Adapun teknik penelitian yang dilakukan dalam penelitian ini yaitu dengan menggunakan metode agih. Metode agih adalah metode analisis data yang alat penentunya merupakan bagian atau unsur dari bahasa objek penelitian itu sendiri (Sudaryanto dalam Santoso, 2012:2). Adapun unsur bahasa dari objek penelitian ini adalah wacana berupa artikel bertema pendidikan.

Teknik dasar metode agih yang digunakan dalam penelitian ini adalah teknik bagi unsur langsung. Teknik bagi unsur langsung yaitu membagi satuan bahasa pada data yang akan dianalisis menjadi beberapa bagian atau unsur (Sudaryanto dalam Santoso, 2012:2). Dalam hal ini, peneliti membagi suatu wacana menjadi beberapa kalimat untuk dianalisis penanda kohesi gramatikal dan leksikalnya.

Penelitian ini difokuskan pada jenis kohesi gramatikal dan leksikal yang paling banyak ditemukan pada artikel pendidikan karya Syarifudin Yunus di laman web Kompasiana. Peneliti akan mengambil 50\% judul pada artikel 2019 dan 50\% juga pada artikel tahun 2020. Subfokus penelitian ini adalah sebagai berikut : 1). Jenis kohesi gramatikal dan leksikal yang terdapat pada artikel pendidikan karya Syarifudin Yunus; 2). Aspek kohesi gramatikal yang terdiri atas referensi, substitusi, konjungsi, dan elipsis; 3). Aspek kohesi leksikal yang diteliti terdiri atas repetisi, sinonimi, antonimi, hiponim, kolokasi dan ekuivalensi.

Instrumen dalam penelitian ini terdiri atas peneliti sendiri, tabel analisis, dan objek yang akan diteliti. Peneliti sendiri (human instrument) yang berperan sebagai kunci instrumen dalam melakukan penelitian ini. Tabel analisis berperan sebagai instrumen pendukung untuk membantu peneliti melakukan penelitian. Adapun objek yang akan diteliti, yaitu artikel Syarifudin Yunus bertema pendidikan pada laman web Kompasiana.

Teknik pencatatan data yang digunakan dalam penelitian ini sebagai berikut: 1). Mendata artikel yang akan diteliti, 2). Membaca dan memahami keseluruhan isi artikel, 3). Memindahkan setiap kalimat ke tabel 1 dan tabel 2,4). Mengidentifikasi dan menjelaskan kohesi gramatikal dan leksikal pada setiap kalimat di tabel 1 dan 2, 5). Menghitung dan mempersentasekan temuan kohesi gramatikal dan leksikal ke tabel 3, 6). Membuat simpulan hasil temuan kohesi gramatikal dan leksikal pada artikel, 7). Membuat interpretasi hasil penelitian.

Teknik pemeriksaan keabsahan data yang digunakan dalam penelitian ini adalah triangulasi data. Triangulasi merupakan usaha memeriksa kebenaran data atau informasi yang diperoleh peneliti dari berbagai sudut pandang dengan cara mengurangi sebanyak mungkin bias yang terjadi pada saat pengumpulan dan analisis data (Rahardjo, 2010:2). Menurut Norman K. Denkin (dalam Rahardjo, 2010:3), triangulasi meliputi empat hal, yaitu: (1) triangulasi metode, (2) triangulasi antar-peneliti, (3) triangulasi sumber data, dan (4) triangulasi teori. Adapun jenis triangulasi yang digunakan dalam penelitian ini adalah triangulasi antar-peneliti. Peneliti mengandalkan pengetahuan dan wawasan mengenai informasi yang diperoleh. Selain itu, peneliti juga dibantu oleh dosen pembimbing sebagai orang yang sudah ahli di bidang linguistik dan pendidikan. Peneliti membangun komunikasi, meminta bimbingan dan arahan, serta koreksi dari dosen pembimbing sehingga penelitian ini dapat mengurangi bias dan pendapat subjektif peneliti sendiri.

\section{Hasil dan Diskusi}

Berdasarkan hasil observasi peneliti, jumlah artikel bertema pendidikan yang ditulis oleh Syarifudin Yunus di laman web Kompasiana.com ialah 128 artikel tahun 2019 dan 91 artikel tahun 2020. Peneliti kemudian mengelompokkan artikel tersebut menjadi 14 topik, yaitu : 1). Bahasa dan pendidikan, 2). Bahasa dan sosial, 3). Kebijakan pendidikan, 4). Kegiatan membaca siswa, 5). Kegiatan menulis mahasiswa, 6). Kompetensi menulis, 7). Literasi membaca masyarakat, 8). Lokakarya menulis siswa, 9). Mahasiswa dan perkuliahan, 10). Masalah pendidikan, 11). Narasi pendidikan, 12). Pendidikan anak dan orang tua, 13). Penelitian dalam pendidikan, dan 14). Seminar pendidikan. Dalam penelitian ini, peneliti memilih topik 'Literasi membaca masyarakat' secara acak. Total artikel yang akan dianalisis oleh peneliti sebanyak 24 judul. Berikut judul-judul artikel yang dianalisis penggunaan unsur kohesinya: 
Tabel 1. Judul Artikel Terpilih

\begin{tabular}{|c|c|c|}
\hline $\begin{array}{l}\text { No. } \\
\text { Data }\end{array}$ & Judul Artikel & Tanggal Publikasi \\
\hline 1. & Literasi media sosial warga medsos renda & 5 Januari 2019 \\
\hline 2. & Tidak perlu alasan untuk peduli berantas buta huruf & 20 Januari 2019 \\
\hline 3. & Generasi literat hanya omong kosong & 21 Februari 2019 \\
\hline 4. & Dosen Unindra kelola taman bacaan berkonsep edutainment & 30 Maret 2019 \\
\hline 5. & "Ngabuburit Baca" TBM Lentera Pustaka biasakan anak membaca & 1 Juni 2019 \\
\hline 6. & Butuh sikap konsisten dalam kampanyekan budaya literasi & 15 Juni 2019 \\
\hline 7. & Tingkat literasi rendah, masyarakat dihantui 7 persoalan besar & 16 Juli 2019 \\
\hline 8. & Membaca berlatar batubata, spot foto di taman bacaan Lentera Pustaka & 4 Agustus 2019 \\
\hline 9. & Sambut hari aksara, geber bura mantapkan berantas buta huruf & 23 Agustus 2019 \\
\hline 10 & Spirit berantas buta aksara geber bura Lentera Pustaka & 25 Agustus 2019 \\
\hline 11 & Cara unik pegiat literasi ngajar kaum buta aksara di kaki gunung salak & 16 September 2019 \\
\hline 12 & Fakta orang Indonesia. Membaca 30 menit, main gawai 5 jam sehari & 11 Desember 2019 \\
\hline 13 & Agil dan "Imah Baca" di kaki gunung salak & 5 Februari 2020 \\
\hline 14 & Kampanye "Ayo baca via hidangan tuhan" ala TBM Lentera Pustaka & 7 Januari 2020 \\
\hline 15 & Kisah perjuangan pegiat literasi membangun tradisi baca di kaki gunung salak Bogor & 18 Maret 2020 \\
\hline 16 & Edukasi virus corona dan pembagian masker anak-anak taman bacaan & 10 April 2020 \\
\hline 17 & Video : Anak-anak kampung merdeka di taman baca & 11 Agustus 2020 \\
\hline 18 & Kampanye "Ayo Baca ke TBM", ajak anak ke taman bacaan saat pjj dan covid 19 & 26 Agustus 2020 \\
\hline 19 & Belajar di kebun baca Lentera Pustaka & 29 Agustus 2020 \\
\hline 20 & Praktik baik TBM Lentera Pustaka, ajarka anak membaca buku di alam & 30 Agustus 2020 \\
\hline 21 & Hari aksara internasional dan krisis literasi & 08 September 2020 \\
\hline 22 & Tingkat literasi masyarakat Indonesia rendah, inilah 6 dampaknya & 27 November 2020 \\
\hline 23 & Guru yang enterpreneur berbagi peduli ke taman bacaan lentera pustaka & 29 November 2020 \\
\hline 24 & Kisah anak-anak kaki gunung salak membaca di senja hari & 9 Desember 2020 \\
\hline
\end{tabular}

Hasil analisis peneliti mengenai penggunaan kohesi gramatikal dan leksikal berjumlah 2111 temuan, dengan rincian 821 temuan kohesi gramatikal dan 1290 temuan kohesi leksikal. Penggunaan kohesi gramatikal terbanyak adalah konjungsi, yaitu 53.7\% dari total temuan. Selanjutnya, disusul dengan $35.6 \%$ referensi, $6.6 \%$ substitusi, dan $4.1 \%$ elipsis. Adapun penggunaan kohesi leksikal terbanyak adalah repetisi, yaitu $63.5 \%$ dari total temuan. Berikutnya disusul dengan $14 \%$ ekuivalensi, $8.8 \%$ kolokasi, $7.2 \%$ sinonimi, $3.8 \%$ hiponim, dan $2.7 \%$ antonimi.

Tabel 2 Rekapitulasi Temuan Kohesi Gramatikal

\begin{tabular}{llll}
\hline No & Unsur Kohesi & Total Temuan & Persentase Temuan \\
\hline 1. & Referensi & 288 & $35.4 \%$ \\
2. & Substitusi & 50 & $6.1 \%$ \\
3. & Konjungsi & 443 & $54.4 \%$ \\
4. & Elipsis & 33 & $4.1 \%$ \\
\hline \multicolumn{2}{l}{ Total Temuan } & 814 & \\
\hline
\end{tabular}

Tabel 2 Rekapitulasi Temuan Kohesi Leksikal

\begin{tabular}{llll}
\hline No & Unsur Kohesi & Total Temuan & Persentase Temuan \\
\hline 1. & Repetisi & 819 & $63.5 \%$ \\
2. & Sinonimi & 93 & $7.2 \%$ \\
3. & Antonimi & 35 & $2.7 \%$ \\
4. & Hiponim & 49 & $3.8 \%$ \\
5. & Kolokasi & 114 & $8.8 \%$ \\
6. & Ekuivalensi & 180 & $14.0 \%$ \\
\hline \multicolumn{2}{l}{ Total Temuan } & 1290 & \\
\hline
\end{tabular}

\section{Pengacuan (referensi)}

Penelitian ini menemukan 292 data yang mengandung aspek pengacuan, baik itu pengacuan persona, pengacuan demonstratif, maupun pengacuan komparatif.

\section{a. Referensi Persona}

Ada sekitar 70 anak yang terbiasa membaca buku 3 kali seminggu di taman bacaan di Kaki Gunung Salak Bogor ini. Mereka berasal dari 3 desa (Sukaluyu-Tamansari-Sinarwangi). (Data 1, paragraf 1)

Kata mereka merupakan referensi persona yang mengacu pada kata 70 anak, termasuk pengacuan anafora karena satuan acuannya berada di kiri atau kalimat sebelumnya. Hal ini sesuai dengan teori Halliday dan Hasan (dalam Hardiaz, 2020:10) dan penelitian yang dilakukan oleh Sutanto (2007:73) bahwa referensi 
persona merupakan penunjukkan yang mengacu pada orang atau yang diorangkan. Analisis di atas menunjukkan referensi persona berupa kata ganti orang ketiga, yaitu kata mereka.

\section{b. Referensi Demonstratif}

Selain Jumat dan Minggu, setiap hari Rabu senja, anak-anak TBM Lentera Pustaka membaca. Atau biasa disebut "jam baca" mulai pukul 15.00-17.30 WIB. Ada sekitar 70 anak yang terbiasa membaca buku 3 kali seminggu di taman bacaan di Kaki Gunung Salak Bogor ini. (Data 1, paragraf 1)

Kata ini merupakan referensi demonstratif yang mengacu pada kata TBM Lentera Pustaka, termasuk pengacuan anafora karena satuan acuannya berada di kiri atau kalimat sebelumnya. Hal ini sesuai dengan teori Sumarlam (dalam Sutanto, 2007:25) dan penelitian yang dilakukan oleh Sutanto (2007:75) bahwa referensi demonstratif merupakan acuan yang mengacu pada kata ganti penunjuk. Analisis di atas menunjukkan referensi demonstratif tempat yang dekat dengan pembicara, yaitu kata ini.

\section{c. Referensi Komparatif}

Anak-anak yang sebelumnya tidak punya akses bacaan itu, kini sudah terbiasa membaca. Apa adanya dan tetap rajin ke taman bacaan. Persis, seperti senja yang selalu menerima langit apa adanya. (Data 1, paragraf 5)

Kata seperti merupakan referensi komparatif yang mengacu pada kalimat sebelumnya, termasuk referensi anafora karena satuan acuannya berada di kiri atau kalimat sebelumnya. Hal ini sesuai dengan teori Sumarlam (dalam Hardiaz, 2020:12) dan penelitian yang dilakukan oleh Sutanto (2007:81-82) bahwa referensi komparatif merupakan salah satu jenis kohesi gramatikal yang bersifat membandingkan dua hal atau lebih yang memiliki kemiripan atau kesamaan dari segi bentuk/wujud, sifat, watak, perilaku, dan sebagainya. Analisis di atas menunjukkan referensi komparatif yang ditandai dengan adanya kata seperti.

\section{Penyulihan (substitusi)}

Penelitian ini menemukan 54 data yang mengandung aspek penyulihan, baik itu penyulihan nominal, penyulihan verbal, penyulihan frasa, dan penyulihan klausa.

\section{a. Substitusi Nominal}

Cara beda inilah yang ditempuh Taman Bacaan Masyarakat (TBM) Lentera Pustaka di Kampung Warung Loa Desa Sukaluyu Kec. Tamansari Bogor. Taman bacaan yang telah beroperasi 3 tahun ini, menerapkan kampanye "Ayo Baca via Hidangan Tuhan", dengan cara membagikan hidangan makan siang kepada jamaah sholat Jumat di Masjid Nurul Iman Desa Sukaluyu. (Data 11, paragraf 2)

Frasa Taman bacaan yang telah beroperasi 3 tahun ini merupakan pengganti dari kata Taman Bacaan Masyarakat (TBM) Lentera Pustaka pada kalimat sebelumnya. Hal ini sesuai dengan teori Sumarlam (dalam Hardiaz, 2020:13) dan penelitian yang dilakukan oleh Aprialdi (2012:46-47) bahwa substitusi nominal merupakan penggantian satuan lingual yang berkategori nomina (kata benda). Analisis di atas menunjukkan substitusi nominal yang ditunjukkan dengan penggantian kata Taman Bacaan Masyarakat (TBM) Lentera Pustaka menjadi frasa Taman bacaan yang telah beroperasi 3 tahun.

\section{b. Substitusi Verbal}

Tujuannya, agar terbentuk kebiasaan membaca anak. Di samping untuk menekan angka putus sekolah. Karena di wilayah ini, tingkat pendidikan masyarakatnya $81 \%$ sebatas SD dan 9\% SMP.

Setelah 3 tahun berjalan pun, kini anak-anak pembaca aktif TBM Lentera Pustaka sudah mampu "melahap" 5-8 buku per minggu. (Data 1, paragraf 14-15)

Kata melahap merupakan pengganti dari kata membaca pada paragraf sebelumnya. Hal ini sesuai dengan teori Sumarlam (dalam Hardiaz, 2020:13) dan penelitian yang dilakukan oleh Aprialdi (2012:5556) bahwa substitusi verbal merupakan penggantian satuan lingual yang berkategori verba (kata kerja). Analisis di atas menunjukkan substitusi verbal yang ditunjukkan dengan penggantian kata membaca menjadi kata melahap.

\section{c. Substitusi Frasal}

Selain Jumat dan Minggu, setiap hari Rabu senja, anak-anak TBM Lentera Pustaka membaca. Atau biasa disebut "jam baca" mulai pukul 15.00-17.30 WIB. Ada sekitar 70 anak yang terbiasa membaca buku 3 kali seminggu di taman bacaan di Kaki Gunung Salak Bogor ini. (Data 1, paragraf 1) 
Frasa di taman bacaan di Kaki Gunung Salak Bogor merupakan pengganti dari frasa TBM Lentera Pustaka pada kalimat sebelumnya. Hal ini sesuai dengan teori Sumarlam (dalam Hardiaz, 2020:14) dan penelitian yang dilakukan oleh Aprialdi (2012:71) bahwa substitusi frasa merupakan penggantian satuan lingual yang berupa kata atau frasa dengan satuan lingual lainnya berupa frasa. Analisis di atas menunjukkan substitusi frasa yang ditunjukkan dengan penggantian frasa TBM Lentera Pustaka menjadi frasa di taman bacaan di kaki Gunung Salak Bogor.

\section{d. Substitusi Klausal}

Poin pentingnya, siapapun harus terlibat dalam mewujudkan masyarakat yang literat. Masyarakat yang sadar belajar dan sadar informasi. (Data 4, paragraf 10)

Klausa Masyarakat yang sadar belajar dan sadar informasi merupakan pengganti dari frasa masyarakat yang literat pada kalimat sebelumnya. Hal ini sesuai dengan teori Sumarlam (dalam Hardiaz, 2020:14) dan penelitian yang dilakukan oleh Aprialdi (2012:153) bahwa substitusi klausa merupakan penggantian satuan lingual yang berupa klausa atau kalimat dengan satuan lingual lainnya berupa kata atau frasa. Analisis di atas menunjukkan substitusi klausa yang ditunjukkan dengan penggantian frasa masyarakat yang literat menjadi klausa masyarakat yang sadar belajar dan sadar informasi.

\section{Pelesapan (elipsis)}

Penelitian ini menemukan 34 data yang mengandung aspek pelesapan, baik itu pelesapan nominal, pelesapan verbal, pelesapan frasa, dan pelesapan klausa.

\section{a. Elipsis Nominal}

Maka sebagian anak, butuh waktu sekitar 20-30 menit berjalan kaki menuju taman bacaan. Atau diantar oleh orang tua mereka. Apalagi di musim hujan seperti sekarang, Ø membaca di TBM Lentera Pustaka bisa jadi sebuah perjuangan. (Data 1, paragraf 2)

Pelesapan nomina berupa kata anak. Hal ini sesuai dengan teori Wiyanti (2016:193) dan penelitian yang dilakukan oleh Wiyanti (2016:199-201) bahwa elipsis nominal merupakan pengilangan satuan lingual berupa kata benda atau frasa nominal. Analisis di atas menunjukkan adanya elipsis nominal berupa kata anak pada kalimat ketiga.

\section{b. Elipsis Verbal}

Wabah virus corona bukan hanya merepotkan kaum dewasa. Tapi juga Ø anak-anak. (Data 9, paragraf 1)

Pelesapan verba berupa kata merepotkan. Hal ini sesuai dengan teori Wiyanti (2016:193) dan penelitian yang dilakukan oleh Wiyanti (2016:193) bahwa elipsis verbal merupakan pengilangan satuan lingual berupa kata kerja. Analisis di atas menunjukkan adanya elipsis verbal berupa kata merepotkan pada kalimat kedua.

\section{c. Elipsis Klausa}

Sebut saja, alokasi waktu membaca orang Indonesia per hari rata-rata hanya 30-59 menit. Masih kurang dari satu jam. (Data 3, paragraf 1)

Pelesapan klausa yaitu alokasi waktu membaca. Hal ini sesuai dengan teori Wiyanti (2016:193) dan penelitian yang dilakukan oleh Wiyanti (2016:193) bahwa elipsis klausa merupakan pengilangan satuan lingual berupa klausa. Analisis di atas menunjukkan adanya elipsis klausa pada kalimat kedua, yaitu klausa alokasi waktu membaca.

\section{Perangkaian (konjungsi)}

Penelitian ini menemukan 443 data yang mengandung aspek perangkaian, baik itu perangkaian aditif, perangkaian adversatif, perangkaian kausal, dan perangkaian temporal.

\section{a. Konjungsi Aditif}

Selain Jumat dan Minggu, setiap hari Rabu senja, anak-anak TBM Lentera Pustaka membaca. Atau biasa disebut "jam baca" mulai pukul 15.00-17.30 WIB. (Data 1, paragraf 1)

Konjungsi aditif yaitu kata atau yang menambahkan penjelasan dari kalimat sebelumnya. Hal ini sesuai dengan teori Achmad (dalam Setiawati dan Pratiwi, 2016:48) dan penelitian yang dilakukan oleh Hardiaz (2020:37) bahwa konjungsi aditif merupakan hubungan atau pertalian yang bersifat penambahan atau penjumlahan antara dua proposisi atau lebih yang dinyatakan oleh penulis. Analisis di atas menunjukkan konjungsi aditif ditandai dengan adanya kata atau.

\section{b. Konjungsi Adversatif}


Anak-anak di Kaki Gunung Salak yang membaca di senja hari. Sebuah pemandangan yang sulit lagi ditemukan di era digital. Sementara banyak anak menyerbu gawai, bermain game online atau menonton TV. (Data 1, paragraf 3-4)

Konjungsi adversatif yaitu kata sementara yang menunjukkan hubungan pertentangan dengan paragraf sebelumnya. Hal ini sesuai dengan teori Achmad (dalam Setiawati dan Pratiwi, 2016:48) dan penelitian yang dilakukan oleh Hardiaz (2020:36-37) bahwa konjungsi adversatif merupakan pertalian perlawanan yang bermakna mempertentangkan suatu hal, keadaan, atau perbuatan. Analisis di atas menunjukkan konjungsi adversatif ditandai dengan adanya kata sementara.

\section{c. Konjungsi Kausal}

Karena membaca buku, bukan hanya menambah pengetahuan dan wawasan mereka. (Data 1, paragraf 9)

Konjungsi kausal yaitu kata karena yang menunjukkan hubungan sebab-akibat dengan paragraf sebelumnya. Hal ini sesuai dengan teori Achmad (dalam Setiawati dan Pratiwi, 2016:48) dan penelitian yang dilakukan oleh Hardiaz (2020:46) bahwa konjungsi kausal merupakan hubungan atau pertalian sebabakibat yang terjadi bila satu proposisi yang lain menjadi akibat atau sebaliknya. Analisis di atas menunjukkan konjungsi kausal ditandai dengan adanya kata karena.

\section{d. Konjungsi Temporal}

Kebun itulah tempat tumbuhnya pepohonan, tanaman. Dari benih yang kecil, disirami, dan dirawat, disirami, hingga tumbuh "pegangan akar" yang kokoh. Lalu, berbuah. (Data 6, paragraf 2)

Konjungsi temporal yaitu kata lalu yang menunjukkan tahapan peristiwa dengan kalimat sebelumnya. Hal ini sesuai dengan teori Achmad (dalam Setiawati dan Pratiwi, 2016:48) dan penelitian yang dilakukan oleh Hardiaz (2020:43) bahwa konjungsi temporal merupakan hubungan atau pertalian waktu antara proposisi dengan proposisi yang lain menunjukkan terjadinya peristiwa dari tahap awal dan dilanjutkan dengan tahap berikutnya. Analisis di atas menunjukkan konjungsi temporal ditandai dengan adanya kata lalu.

\section{Repetisi}

Penelitian ini menemukan 819 data yang mengandung aspek repetisi.

Sebut saja, alokasi waktu membaca orang Indonesia per hari rata-rata hanya 30-59 menit. Masih kurang dari satu jam. Sedangkan, jumlah buku yang dibaca tuntas per tahun rata-rata hanya 5-9 buku (Perpusnas, 2017). Sementara standar UNESCO meminta agar waktu membaca tiap orang sekitar 4-6 jam per hari. Sementara masyarakat di negara maju rata-rata menghabiskan waktu membaca 6-8 jam per hari. (Data 3, paragraf 1)

Pengulangan frasa waktu membaca menunjukkan bagian kata yang dianggap penting atau kata kunci dari paragraf tersebut. Hal ini sesuai dengan teori Sumarlam (dalam Hardiaz, 2020:16) dan penelitian yang dilakukan oleh Telaumbanua, dkk. (2019:92) bahwa repetisi merupakan pengulangan satuan lingual (bunyi, suku kata, kata, atau bagian kalimat) yang dianggap penting untuk memberi tekanan dalam sebuah konteks yang sesuai. Analisis di atas menunjukkan adanya repetisi yang dibuktikan dengan pengulangan frasa waktu membaca.

\section{Sinonimi}

Penelitian ini menemukan 93 data yang mengandung aspek sinonimi.

Maka jangan lengah. Orang dewasa tidak boleh lalai. Taman bacaan pun harus terus berjuang. Agar mampu mengembalikan anak-anak Indonesia untuk membaca buku. (Data 1, paragraf 8)

Sinonimi kata lengah dan kata lalai menunjukkan hubungan kohesi antarkalimatnya. Hal ini sesuai dengan teori Sumarlam (dalam Hardiaz, 2020:16) dan penelitian yang dilakukan oleh Sulistyaningsih (2020:6) bahwa sinonimi merupakan nama lain untuk benda atau hal yang sama; atau ungkapan lain. Analisis di atas menunjukkan adanya sinonimi kata lengah dan lalai.

\section{Antonimi}

Penelitian ini menemukan 35 data yang mengandung aspek antonimi. 
Anak-anak era digital lebih gemar bermain gawai atau bermain game online. Tidak salah sih, tapi kurang seimbang bila tidak membaca. Maka patut diduga, itulah sebab "perginya" minat baca anak-anak di Indonesia. (Data 1, paragraf 7)

Antonimi kata lebih dan kata kurang menunjukkan hubungan kohesi antarkalimatnya. Hal ini sesuai dengan teori Verhaar (dalam Khairunisa, 2019:8) dan penelitian yang dilakukan oleh Hardiaz (2020:54) bahwa antonimi merupakan ungkapan (berupa kata, frasa atau kalimat) yang maknanya berlawanan dari makna ungkapan lain. Analisis di atas menunjukkan adanya antonimi kata lebih dan kata kurang.

\section{Kolokasi}

Penelitian ini menemukan 114 data yang mengandung aspek kolokasi.

Ternyata, kemajuan zaman dan teknologi canggih tidak berbanding lurus dengan meningkatnya kebiasaan membaca orang. Era digital dan revolusi industri 4.0 pun tidak menjamin tegaknya budaya literasi di Indonesia. Bahkan orang makin kaya pun belum tentu makin peduli pada budaya literasi. Justru sebaliknya, di era serba digital dan revolusi industri ini, faktanya makin banyak orang malas membaca, makin malas menulis. Perilaku baca makin terpinggirkan, budaya literasi kian dikebiri. (Data 3, paragraf 3)

Pada paragraf di atas, ditemukan kolokasi kata kebiasaan membaca, budaya literasi, membaca, menulis, dan perilaku baca. Hal ini sesuai dengan teori Sumarlam (dalam Hardiaz, 2020:17) dan penelitian yang dilakukan oleh Hardiaz (2020:55) bahwa kolokasi merupakan asosiasi tertentu dalam menggunakan pilihan kata yang cenderung digunakan secara berdampingan. Analisis di atas menunjukkan adanya kolokasi antara kata kebiasaan membaca, budaya literasi, membaca, menulis, dan perilaku baca.

\section{Hiponimi}

Penelitian ini menemukan 49 data yang mengandung aspek hiponimi.

Siapa yang tidak tahu kebun? Pasti semua tahu. Kebun itulah tempat tumbuhnya pepohonan, tanaman. Dari benih yang kecil, disirami, dan dirawat, disirami, hingga tumbuh "pegangan akar" yang kokoh. Lalu, berbuah. (Data 6, paragraf 1-2)

Kata pepohonan, tanaman, benih, dan berbuah merupakan hiponim dari kata kebun. Hal ini sesuai dengan teori Sumarlam (dalam Hardiaz, 2020:17) dan penelitian yang dilakukan oleh Hardiaz (2020:5758) bahwa hiponimi merupakan satuan bahasa (kata, frasa, kalimat) yang maknanya dianggap merupakan bagian dari makna satuan lingual lain. Analisis di atas menunjukkan adanya hiponimi dari kata kebun yang dibuktikan dengan kata pepohonan, tanaman, benih, dan berbuah.

\section{Ekuivalensi}

Penelitian ini menemukan 180 data yang mengandung aspek ekuivalensi.

...Tidak mungkin bisa baca, orang-orang yang tidak senang. "TBM Lentera Pustaka hadir di Desa Sukaluyu untuk membiasakan anak-anak membaca, di samping memberi akses bacaan... (Data 1, paragraf 17-18)

Adanya hubungan makna antara kata baca, membaca, dan bacaan. Hal ini sesuai dengan teori Sumarlam (dalam Hardiaz, 2020:18) dan penelitian yang dilakukan oleh Hardiaz (2020:58) bahwa ekuivalensi merupakan hubungan kesepadanan antara satuan lingual tertentu dengan satuan lingual yang lain dalam sebuah paradigma. Analisis di atas menunjukkan adanya ekuivalensi antara kata baca, membaca, dan bacaan, semuanya dari bentuk asal yang sama yaitu kata baca.

\section{Simpulan}

Berdasarkan hasil penelitian yang diperoleh dari artikel bertema pendidikan karya Syarifudin Yunus di Kompasiana ditemukan empat aspek kohesi gramatikal dan enam aspek kohesi leksikal. Temuan kohesi gramatikal didominasi oleh penggunaan aspek perangkaian atau konjungsi, yakni sebanyak 443 temuan atau 54.4\% dari total temuan. Adapun temuan kohesi leksikal didominasi oleh penggunaan aspek repetisi, yakni sebanyak 819 temuan atau $63.5 \%$ dari total temuan

Penelitian ini dapat diimplikasikan pada pembelajaran Bahasa Indonesia tingkat SMP dan SMA. Implikasi pada tingkat SMP terdapat pada kompetensi dasar 3.6., sedangkan pada tingkat SMA terdapat 
pada kompetensi dasar 3.3. Implikasi yang dapat diterapkan dari penelitian ini di antaranya: 1). Meningkatkan kemampuan menulis peserta didik; 2). Memberikan pemahaman terkait kepaduan menulis wacana peserta didik, terutama unsur kohesi gramatikal dan leksikalnya; 3). Meningkatkan kemampuan berpikir kritis siswa terhadap pemberitaan yang ada di media massa dengan menuliskannya dalam bentuk wacana yang padu dan kohesif; 4). Menganjurkan kepada pendidik untuk menggunakan laman web Kompasiana sebagai media pembelajaran bahasa Indonesia.

Peneliti menyadari masih banyak kekurangan yang terdapat dalam penelitian ini, di antaranya: 1). Peneliti hendaknya lebih cermat dalam mengidentifikasi unsur kohesi gramatikal, khususnya pada konsep substitusi dan elipsis. Hal ini dikarenakan keduanya bersifat tersirat, berbeda dengan konsep referensi dan konjungsi yang bersifat tersurat; 2). Peneliti hendaknya dapat lebih memfokuskan terhadap salah satu konsep yang ada pada unsur kohesi gramatikal dan/atau leksikal. Hal ini bertujuan agar penelitian dapat lebih banyak memaparkan teori dengan lebih merinci; 3). Dalam meneliti unsur kohesi leksikal, hendaknya peneliti dapat menemukan metode yang lebih mudah dalam penelitiannya. Hal ini dikarenakan unsur kohesi leksikal bukan hanya membuktikan kekohesifan antar kalimat, melainkan juga antarparagraf. Oleh karena itu, dibutuhkan metode yang tepat untuk meneliti unsur kohesi leksikal agar mendapatkan hasil yang sesuai.

\section{Ucapan Terima Kasih}

Peneliti mengucapkan terima kasih kepada dosen pembimbing materi dan teknik yang telah membimbing dalam penyusunan artikel ilmiah ini. Peneliti juga mengucapkan terima kasih kepada Mamah yang senantiasa memberikan semangat dan dukungan yang luar biasa.

\section{Daftar Rujukan}

Achmad. Aspek Kohesi Wacana. Jakarta: Fakultas Bahasa dan Seni UNJ, 2005

Amin, Muhammad, Syamsudin Syamsudin, dan Sugit Zulianto. "Kohesi dan Koherensi dalam Artikel Ilmiah Populer Radar Sulteng." BAHASANTODEA 4.3 (2016): 48-56.

Aprialdi, Evan. "Penanda Kohesi Substitusi dalam Novel Ronggeng Dukuh Paruk karya Ahmad Tohari dan Implikasinya pada Pembelajaran Bahasa Indonesia di Sekolah Menengah Atas (SMA)." Keguruan dan Ilmu Pendidikan, Pendidikan Bahasa dan Seni, Universitas Lampung (2012).

Arifin, E. Zainal, dkk. Wacana Transaksional dan Interaksional dalam Bahasa Indonesia. Tangerang: PT Pustaka Mandiri, 2015.

Astuti, Sri Puji. "Kohesi dalam Novel Surat Kecil untuk Tuhan.” Jurnal NUSA 14 (2019): 364-375.

Djajasudarma, T. Fatimah. Wacana Pemahaman dan hubungan Antarunsur. Bandung: PT Eresco, 1994.

Dwinuryati, Yustina., dkk. "Analisis Kohesi Gramatikal dan Leksikal pada Teks Eksposisi Siswa Kelas 10 Sekolah Menengah Atas.” Jurnal Scholaria 8 (2018): 61-69.

Hardiaz, Rita Mey. "Kohesi Gramatikal Dan Kohesi Leksikal Dalam Novel Kubah Karya Ahmad Tohari Dan Implikasinya Terhadap Pembelajaran Bahasa Indonesia di SMA.” Keguruan dan Ilmu Pendidikan, Pendidikan Bahasa dan Sastra, Universitas Pancasakti Tegal (2020).

Hasibuan, Asrul Khairi. "Analisis Penanda Kohesi Gramatikal Artikel Politik pada Media Online Kompasiana.com." Bahasa dan Seni, Bahasa dan Sastra Indonesia, Universitas Negeri Medan (2016).

Khairunisa, Hanifa Dwinda. "Kohesi Leksikal dan Kohesi Gramatikal dalam Novel Hujan Karya Tere Liye.” Jurnal UNDIP (2019).

Kompasiana.com. "Infografis Statistik Kompasiana." www.kompasiana.com. 2017. 17 Januari 2021.

Kompasiana.com. "Kompasiana Masuk 10 Besar Media Digital Terbesar di Indonesia." www.kompasiana.com. 16 Februari 2018. 17 Januari 2021.

Kompasiana.com. "Profil Syarifudin Yunus di Kompasiana." (2012). www.kompasiana.com. 2012. 7 Januari 2021.

Kompasiana.com. "Tentang Kompasiana.” www.kompasiana.com. 2017. 17 Januari 2021.

Mulyana. Kajian Wacana: Teori, Metode, dan Aplikasi Prinsip-prinsip Analisis Wacana. Yogyakarta: Tiara Wacana, 2005.

n.p. "Metode Penelitian Bahasa: Metode Agih, Teknik Dasar dan Lanjutan." www.sastra33.blogspot.com. 8 Mei 2014. 10 Februari 2021.

Rahardjo, Mudjia. "Triangulasi dalam Penelitian Kualitatif." (2010). www.uin-malang.ac.id. 15 Oktober 2010. 31 Januari 2021. 
Setiawati, Sulis \& Heppy Atma Pratiwi. “Aspek Kohesi Konjungsi dalam Wacana Opini pada Majalah Tempo dan Implikasinya terhadap Pembelajaran Bahasa Indonesia.” Jurnal Gramatika 1 (2016): 45-56.

Sudaryanto. Metode dan Aneka Teknik Analisis Bahasa: Pengantar Penelitian Wahana Kebudayaan secara Linguistis. Yogyakarta: Duta Wacana University Press, 1993.

Sulistyaningsih, Anita. "Kohesi dan Koherensi dalam Teks Eksplanasi Karangan Siswa Kelas VIII SMPN 3 Colomadu Karanganyar." Jurnal (2020).

Sumarlam. Analisis Wacana Teori dan Praktik. Surakarta: Pustaka Cakra, 2008.

Sumarlam. Teori dan Praktik Analisis Wacana. Surakarta: Pustaka Cakra, 2003.

Sutanto, Dwi. "Referensi dalam Wacana Tulis Berbahasa Indonesia di Surat Kabar." Bahasa dan Seni, Sastra Indonesia, Universitas Negeri Semarang (2007).

Telaumbanua, Sadieli dkk. "Analisis Kohesi dan Koherensi dalam Teks Eksplanasi Siswa di Kelas XI SMA YPN Marisi Medan Tahun Pelajaran 2018/2019.” Jurnal (2019): 86-96.

Wiyanti, Endang. "Kajian Kohesi Gramatikal Substitusi dan Elipsis dalam Novel Laskar Pelangi Karya Andrea Hirata." Jurnal Pendidikan Bahasa dan Sastra 16 (2016): 188-202. 